\title{
Gas chromatography-mass spectrometry analysis, antimicrobial, anticancer and antioxidant activities of $n$-hexane and methylene chloride extracts of Senna italica
}

\author{
Hassan M.F. Madkour ${ }^{1}$, Mosad A. Ghareeb ${ }^{2 *}$, Mohamed S. Abdel-Aziz ${ }^{3}$, Omar M. Khalaf ${ }^{1}$, Amal M. Saad ${ }^{2}$, \\ Ahmed K. El-Ziaty ${ }^{1}$, Mamdouh Abdel-Mogib ${ }^{4}$ \\ ${ }^{1}$ Chemistry Department, Faculty of Science, Ain Shams University, El-Khalifa El-Mamoun, 11566 Abbassia, Cairo, Egypt. ${ }^{2}$ Medicinal Chemistry \\ Department, Theodor Bilharz Research Institute, Kornaish El-Nile, 12411 Warrak El-Hadar, Imbaba (P.O. 30), Giza, Egypt. ${ }^{3}$ Microbial Chemistry \\ Department, Genetic Engineering and Biotechnology Division, National Research Center, El Behoos Street 33, Dokki-Giza, Egypt. ${ }^{4}$ Chemistry Department, \\ Faculty of Science, Mansoura University, Mansoura-35516, Mansoura, Egypt.
}

\section{ARTICLE INFO \\ Article history: \\ Received on: 21/12/2016 \\ Accepted on: 09/02/2017 \\ Available online: $30 / 06 / 2017$}

\section{Key words:}

Senna italica;

antimicrobial;anticancer;

ABTS; GC-MS analysis.

\begin{abstract}
The current study was aimed to investigate the antimicrobial, anticancer, and antioxidant activities of the $n$ hexane and methylene chloride extracts from Senna italica as well as the characterization of their chemical constituents via gas chromatography-mass spectrometry analysis (GC-MS). The results revealed that the $n$ hexane extract showed weak antimicrobial activity with inhibition zones were ranged from 3.8 to $7 \mathrm{~mm}$, and the methylene chloride extract showed a potent antimicrobial activity with inhibition zones were ranged from 4.2 to $18 \mathrm{~mm}$ compared to five standard antibiotics. Also, according to the criteria of the American National Cancer Institute (USNCI), the $n$-hexane showed weak anticancer activity with $\mathrm{IC}_{50}$ equal to $81.6 \pm 4.1,73.0 \pm 3.90$, $66.8 \pm 3.12$, and $92.8 \pm 4.82 \mu \mathrm{g} / \mathrm{ml}$, while the methylene chloride exhibited a potent anticancer activity with $\mathrm{IC}_{50}$ of $16.9 \pm 1.30,17.4 \pm 1.36,18.3 \pm 1.59$, and $14.2 \pm 1.18 \mu \mathrm{g} / \mathrm{ml}$, compared to 5-fluorouracil with $\mathrm{IC}_{50}$ of $7.9 \pm 0.28$, $4.8 \pm 0.21,8.3 \pm 0.35$, and 5.4 \pm 0.20 , all respectively for HePG-2, Hela, PC3, and MCF-7 tumor cell lines. The activity against ABTS radical was recorded with the methylene chloride (\% inhibition $=86.3 \%)$, compared to ascorbic acid with $89.2 \%$. Moreover, GC-MS analysis revealed that the major constituents of the $n$-hexane were $n$-hexadecanoic acid (30\%), (Z,Z,Z)9,12,15-octadecadienoic acid (21\%), vitamin E (7.32\%), and for methylene chloride were 3-methyl-4-oxopentanoic acid (16.36\%), (E)-stilbene (11.86\%), and 2,6-di-tert-butylphenol $(10.70 \%)$.
\end{abstract}

\section{INTRODUCTION}

Senna L. (Fabaceae) is a widespread genus of flowering plants growing in the tropical and subtropical regions around the world i.e., Latin \& North America, Africa, Southeastern Asia, and Australia (Yagi et al., 2013). Senna comprised nearly 350 species (Randell and Barlow, 1998; Yagi et al., 2013). For a long time different species belonging to this genus are used

* Corresponding Author

Mosad A. Ghareeb, Medicinal Chemistry Department, Theodor Bilharz Research Institute, Kornaish El-Nile, 12411 Warrak El-Hadar, Imbaba (P.O.30), Giza, Egypt. Email: m.ghareeb @ tbri.gov.eg traditionally to treat many ailments such as intestinal disorders, anti-tick, rheumatic, sexually transmitted diseases, laxative, and purgative (Al-Said 1993;Tshikalange et al., 2005;Magano et al., 2008;Hennebelle et al., 2009;Masoko et al., 2010). Senna italica is native to many regions in Africa. The plant has a great history in the folk medicine for the treatment of many diseases and pains (Al-Said, 1993; Maleho, 2015). The literature survey on the plant revealed that the previous chemical investigations on the different partsof $S$. italica led to the separation and characterization of certain phytochemicals viz., physcion, chrysophanol, 10,10'chrysophanol bianthrone, 3,4',5-trihydroxystilbene, 1,8-dihydroxy3-methylanthraquinone and 1,2-benzenedicarboxylic acid (Magano et al., 2008; Mokgotho et al., 2013; Yagi et al., 2013). 
From the biological activity point of view, different parts of the plants were reported for their vital biological activities i.e., antioxidant (Jothi et al., 2015), cytotoxicity (Kuete et al., 2013), antibacterial (Masoko et al., 2010; Dabai et al., 2012), and and antiproliferative (Masoko et al., 2010). Since, the microbial resistances against antibiotics is a great challenge and rapidly increase, so scientists search for a new trend aiming to identify naturally occurring antimicrobial agents from medicinal plants as alternative to the current antibiotics (Cowan, 1999; Ghareeb et al., 2015). Cancer is the rapid and uncontrolled cells growth leading to death, and must be fixed by chemotherapy (Ghareeb et al., 2013). The plant derived naturally occurring compounds are considered as good chemotherapeutic anticancer agents (Schwartsmann et al., 2002). Therefore, the current study aims to investigate the chemical constituents of Senna italica aerial parts as well as the evaluation of their in vitro antimicrobial, anticancer, and antioxidant activities.

\section{MATERIALS AND METHODS}

\section{Plant material}

The aerial parts of Senna italica were collected from Alkharga Oasis, Alwady Algaded, Egyptduring March, 2015. The plant was identified by Prof. Dr. Ibrahim A. Mashaly, Professor of Plant Ecology and Flora, Botany Department, Faculty of Science, Mansoura University.

\section{Extraction}

The air dried powdered aerial parts of S. italica (500 g) were soaked in a mixture of organic solvents composed $\mathrm{CH}_{2} \mathrm{Cl}_{2} / \mathrm{MeOH}$ (1:1) for 72 hat room temperature and after filtration, the solvent was evaporated using rotatory evaporator, then the resulting crude extract was undergo further fractionation processusing different organic solvents i.e., $n$-hexane, methylene chloride, ethyl acetate and $n$-butanol.

\section{Antimicrobial activity}

The antimicrobial activity was evaluated by filter paper disc methods(Murray et al., 1998; Sardari et al., 1998).Stock cultures of the test organisms were obtained from the microbiological Laboratory, Faculty of Medicine, Mansoura University. Bacteria test microbes used were Staphylococcus aureus, Streptococcus pyogenes, Klebsiella pneumonia, E. coli, Bacillus subtilis and Erwenia carotovora. Whereas the fungus used was; Candida albicans.

\section{Anticancer activity (MTT assay)}

The anticancer activity was evaluated according to the reported procedure (Mauceri et al., 1998), using four human tumor cell lines namely; hepatocellular carcinoma (HePG-2), mammary gland breast cancer (MCF-7), Human prostate cancer (PC3), and Epitheliod Carcinoma (Hela). The cell lines were obtained from ATCC via Holding company for biological products and vaccines (VACSERA), Cairo, Egypt. Briefly, MTT assay is a colorimetric technique is based on the change of the yellow tetrazolium bromide (MTT) to a purple formazan derivative by mitochondrial succinate dehydrogenase in viable cells. The cells were cultured in RPMI-1640 medium with $10 \%$ fetal bovine serum. Antibiotics added were 100 units $/ \mathrm{ml}$ penicillin and $100 \mu \mathrm{g} / \mathrm{ml}$ streptomycin at $37^{\circ} \mathrm{C}$ in a $5 \% \mathrm{CO}_{2}$ incubator. The cells were seeds in a 96-well plate at a density of $1.0 \times 104$ cells/wellat $37{ }^{\circ} \mathrm{C}$ for $48 \mathrm{hrs}$ under $5 \% \mathrm{CO}_{2}$. After incubation the cells were treated with different concentration of compounds and incubated for $24 \mathrm{hr}$. After $24 \mathrm{~h}$ of drug treatment, $20 \mu \mathrm{l}$ of MTT solution at $5 \mathrm{mg} / \mathrm{ml}$ was added and incubated for $4 \mathrm{hr}$. Dimethyl sulfoxide (DMSO) in volume of 100 $\mu 1$ is added into each well to dissolve the purple formazan formed. The colorimetric assay is measured and recorded at absorbance of $570 \mathrm{~nm}$ using a plate reader (EXL 800, USA). The relative cell viability in percentage was calculated as (A570 of treated samples/A570 of untreated sample) X 100.

\section{Antioxidant activity (ABTS assay)}

The antioxidant activity was evaluated via ABTS method (El-Gazzar et al., 2009).Briefly,2 $\mathrm{ml}$ of ABTS solution $(60 \mathrm{mM})$ was added to $3 \mathrm{M} \mathrm{MnO}_{2}$ solution $(25 \mathrm{mg} / \mathrm{ml})$ all prepared in phosphate buffer ( $\mathrm{pH} 7,0.1 \mathrm{M}$ ). Then, the mixturewasn, centrifuged, filtered, and the absorbance $\left(\mathrm{A}_{\text {control }}\right)$ of the resulting green-blue solution (ABTS radical solution) was adjusted at ca. 0.5 at $734 \mathrm{~nm}$. Then, $50 \mathrm{ml}$ of $(2 \mathrm{mM})$ solution of the test sample in highly grade spectroscopic methanol/phosphate buffer (1:1) was added. The absorbance $\left(\mathrm{A}_{\text {test }}\right)$ was measured and the decrease in color strength was expressed as $\%$ inhibition. The $\%$ inhibition for each sample is calculated according to the following equation:\% Inhibition $=\mathrm{A}_{\text {control }}-\mathrm{A}_{\text {test }} / \mathrm{A}_{\text {control }} \times 100$.Ascorbic acid was used as standard, and the blank sample contain methanol/phosphate buffer (1:1) instead of sample in absence of ABTS. While the negative control sample containmethanol/phosphate buffer $(1: 1)$.

\section{RESULTS AND DISCUSSION Antimicrobial activity}

The antimicrobial potentials of the n-hexane and methylene chloride extracts of Senna italica were examined via disc diffusion assay, using twelve pathogenic microbial species. The results in Table 1 revealed that $n$-hexane extract showed weak to moderate antimicrobial effect against all the tested organisms with inhibition zones ranged from 3.8 to $7 \mathrm{~mm}$. While the methylene chloride extract showed a remarkable effect against eight organisms compared to standard antibiotics i.e., Escherichia coli $(18 \mathrm{~mm} /$ ampicillin24mm), Staphylococcus aureus $(15 \mathrm{~mm} /$ ampicillin $24 \mathrm{~mm})$, Streptococcus pyogenes $(12 \mathrm{~mm} /$ ampicillin $20 \mathrm{~mm})$, Candida albicans (10 mm/ clotrimazole 20mm), Klebsiella pneumoniae $(9.2 \mathrm{~mm} /$ ampicillin 25), Erwinia spp. (9mm/ streptomycin 35mm), Staphylococcus epidermis $(9 \mathrm{~mm} /$ ampicillin $24 \mathrm{~mm})$, andBacillus subtilis $(9 \mathrm{~mm} /$ kanamycin $20 \mathrm{~mm})$. At concentration $30 \mathrm{mg} / \mathrm{ml}$ the $n$-hexane extract of Senna italica leaf growing in Nigeria was tested as antibacterial agent, which showed a strong activity against five bacterial microorganisms namely; 
Table 1: The inhibition zone (mm) and activity index $\%$ of $n$-hexane and methylene chloride extracts of $S$. italica compared to standard antibiotics.

\begin{tabular}{|c|c|c|c|c|c|}
\hline \multirow[b]{2}{*}{ Microorganism } & $\begin{array}{c}\text { Standard } \\
\text { Antibiotic/ }\end{array}$ & \multicolumn{2}{|c|}{$n$-hexane } & \multicolumn{2}{|c|}{ Methylene chloride } \\
\hline & $\begin{array}{l}\text { Inhibition } \\
\text { zone (mm) }\end{array}$ & $\begin{array}{c}\text { Inhibition zone } \\
(\mathbf{m m})\end{array}$ & $\begin{array}{l}\text { Activity } \\
\text { index } \%\end{array}$ & $\begin{array}{c}\text { Inhibition zone } \\
(\mathbf{m m})\end{array}$ & $\begin{array}{l}\text { Activity } \\
\text { index } \%\end{array}$ \\
\hline Klebsiella pneumoniae & Ampicillin/ 25 & 0 & 0 & 9.2 & 36.8 \\
\hline Shigella spp. & Streptomycin/ 14 & 3.8 & 27.1 & 4.2 & 30.0 \\
\hline Erwinia spp. & Streptomycin/ 35 & 0 & 0 & 9 & 25.7 \\
\hline Escherichia coli & Ampicillin/ 24 & 5.2 & 21.6 & 18 & 75 \\
\hline Enterobacter aerogenes & Kanamycin/ 20 & 0 & 0 & 7 & 35.0 \\
\hline Pseudomonas aeruginosa & Tobramycin/ 15 & 4.3 & 28.6 & 8.2 & 54.6 \\
\hline Proteus vulgaris & Ampicillin/ 18 & 0 & 0 & 5.4 & 30.0 \\
\hline Staphylococcus epidermis & Ampicillin/ 24 & 7 & 29.1 & 9 & 37.5 \\
\hline Streptococcus pyogenes & Ampicillin/ 20 & 0 & 0 & 12 & 60 \\
\hline Staphylococcus aureus & Ampicillin/ 24 & 5 & 20.8 & 15 & 62.5 \\
\hline Bacillus subtilis & Kanamycin/ 20 & 0 & 0 & 9 & 45.0 \\
\hline Candida albicans & Clotrimazole/ 20 & 7 & 35.0 & 10 & 50.0 \\
\hline
\end{tabular}

Staphylococcus aureus, Salmonella typhi, Escherichia coli, Pseudomonas aeruginosa and Streptococcus pneumoniae, with inhibition zones of $11.60,11.60,16.0,12.60$, and $14.0 \mathrm{~mm}$ respectively (Dabai et al., 2012).Masoko et al (2010) reported that acetone extract of the roots of Senna italica growing in South Africa showed antibacterial activity against Pseudomonas aeruginosa, Enterococcus faecalis, Escherichia coli and Staphylococcus aureus with MICs ranging from 0.08 to 0.16 $\mathrm{mg} / \mathrm{ml}($ Masoko et al., 2010).Also, another study revealed that the methanolic extract of Cassia italica leaves growing in Iraq showed a significant inhibition in growth of three pathogenic microbial starins, E.coli, Staphylococcus aureus and Candida albicans, exhibited inhibition zones of 15.35, 21.35, and $14.35 \mathrm{~mm}$ respectively at concentration $50 \mathrm{mg} / \mathrm{ml}$ (Al-Naimy et al., 2010).Moreover, As four et al (2015) investigated the $n$-hexane, ethyl acetate, aqueous and total methanol extracts from Cassia italica aerial parts growing in Saudi Arabia exhibited antimicrobial activity. The $n$-hexane exhibited weak effect against two organisms S. aureus $(6 \mathrm{~mm})$ at $500 \mathrm{mg} / \mathrm{ml}$ compared to Gentamycin $(27 \mathrm{~mm} / 50 \mathrm{mg} / \mathrm{ml})$ and C. albicans $(5 \mathrm{~mm})$ compared to Clotrimazole (22mm50 mg/ml)(Asfour et al., 2015).

\section{Anticancer activity}

The $n$-hexane and methylene chloride extracts from the aerial parts of Senna italica were evaluated as anticancer agents against four human tumor cell lines compared to 5-fluorouracil as standard. The results in Table 2 and Figures1 (a-c) revealed that the $n$-hexane showed a weak anticancer activity against HePG2( $\left(\mathrm{IC}_{50} 81.6 \mu \mathrm{g} / \mathrm{ml}\right), \mathrm{MCF}-7\left(\mathrm{IC}_{50}, 92.8 \mu \mathrm{g} / \mathrm{ml}\right)$, PC3 $\left(\mathrm{IC}_{50}, 66.8\right.$ $\mu \mathrm{g} / \mathrm{ml})$, and Hela $\left(\mathrm{IC}_{50}, 73.0 \mu \mathrm{g} / \mathrm{ml}\right)$ compared with 5 -FU with $\mathrm{IC}_{50}$ values of $7.9,5.4,8.3$, and $4.8 \mu \mathrm{g} / \mathrm{ml}$ respectively. On the other hand, the methylene chloride extract showed strong activity against HePG-2(IC $\left.{ }_{50}, 16.9 \mu \mathrm{g} / \mathrm{ml}\right)$, MCF-7 $\left(\mathrm{IC}_{50}, 14.2 \mu \mathrm{g} / \mathrm{ml}\right)$, PC3 $\left(\mathrm{IC}_{50}, 18.3 \mu \mathrm{g} / \mathrm{ml}\right)$, and Hela $\left(\mathrm{IC}_{50}, 17.4 \mu \mathrm{g} / \mathrm{ml} .5-\mathrm{FU}\right.$ exhibited $\mathrm{IC}_{50}$ of 7.9, 4.8, 8.3 and $5.4 \mu \mathrm{g}$ /mlagainst HePG-2,MCF-7, PC3, and Hela respectively. According to the American Cancer Institute (USNCI), the curd extracts are considered to be potent anticancer agents when their $\mathrm{IC}_{50}$ values are less than $20 \mu \mathrm{g} / \mathrm{ml}$
$\left(\mathrm{IC}_{50}<20 \mu \mathrm{g} / \mathrm{ml}\right.$ ) (Suffness and Pezzuto, 1990; Boik, 2001; Ghareeb et al., 2014; Shoeb et al., 2014).

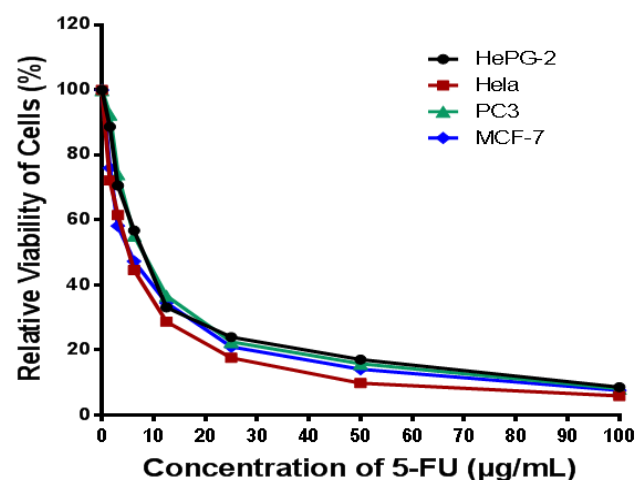

Fig. 1a: Relative viability of cells (\%) against different concentrations 5fluorouracil as standard.

Therefore, then-hexane extract is considered to be weak anticancer, while the methylene chloride showed a potent anticancer activity against four tested tumor cell lines according to USNCI criteria. The acetone extract of Senna italica root inhibited proliferation and viability of Jurkat T cells (Masoko et al., 2010). Kuete et al (2013) found that the $80 \%$ methanol extract of the aerial part from Senna italica growing in Saudi Arabia inhibited the growth of leukemia cancer cell lines CCRF-CEM by 53.57\% and $\mathrm{IC}_{50}$ of $37.13 \mu \mathrm{g} / \mathrm{ml}$, also inhibited the growth of HL60 cancer cell lines by $48.0 \%$ (Kuete et al., 2013).Accordingly, the current findings confirmed the ability to use the plant as a source of naturally occurring anticancer agents.

Table 2: Anticancer activity of n-hexane and methylene chloride extracts of $S$. italica against human tumor cells compared to 5-fluorouracil as standard.

\begin{tabular}{lllll}
\hline \multirow{2}{*}{ Samples } & \multicolumn{4}{c}{ In vitro Cytotoxicity $\mathbf{~ I C}_{\mathbf{5 0}}(\boldsymbol{\mu g} / \mathbf{m l})^{\mathbf{1}}$} \\
\cline { 2 - 5 } & HePG2 & Hela & PC3 & MCF-7 \\
\hline 5-FU ${ }^{2}$ & $7.9 \pm 0.28$ & $4.8 \pm 0.21$ & $8.3 \pm 0.35$ & $5.4 \pm 0.20$ \\
$n$-hexane- & $81.6 \pm 4.15$ & $73.0 \pm 3.90$ & $66.8 \pm 3.12$ & $92.8 \pm 4.82$ \\
$\begin{array}{l}\text { Methylene } \\
\text { chloride }\end{array}$ & $16.9 \pm 1.30$ & $17.4 \pm 1.36$ & $18.3 \pm 1.59$ & $14.2 \pm 1.18$ \\
\hline
\end{tabular}

${ }^{1} \mathrm{IC}_{50}(\mu \mathrm{g} / \mathrm{ml})$ : 1-10 (very strong). 11-20 (strong). 21-50 (moderate). 51-100 (weak) and above 100 (non-cytotoxic). ${ }^{2} 5$-FU $=5$-fluorouracil. 


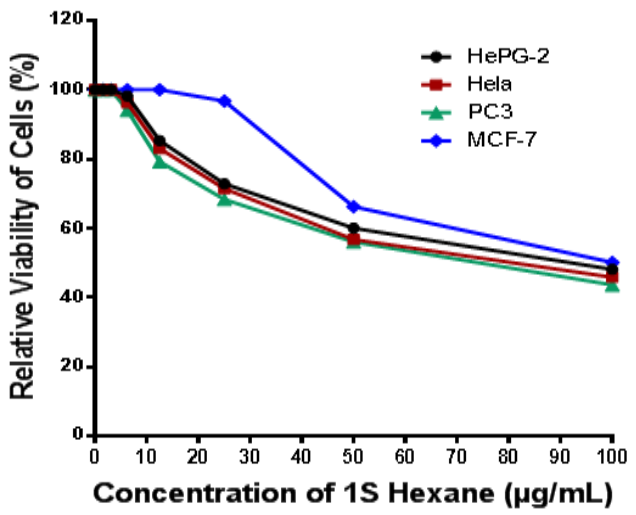

Fig. 1b: Relative viability of cells (\%) against different concentrations of $n$ hexane extract.

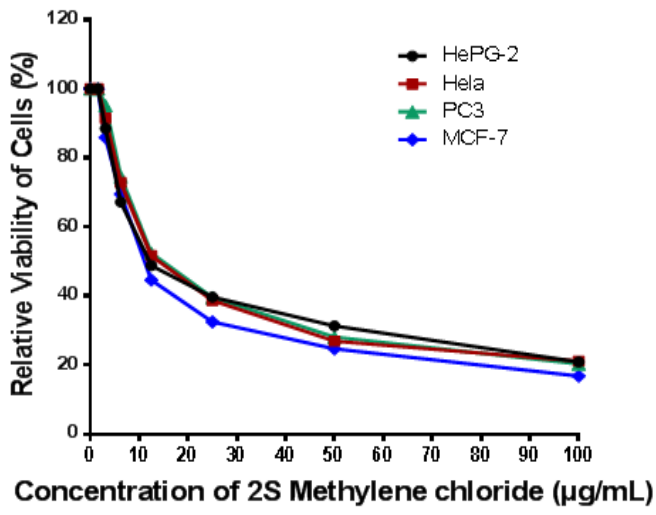

Fig. 1c: Relative viability of cells (\%) against different concentrations of methylene chloride extract.

\section{ABTS free radical scavenging antioxidant activity}

The in vitro free radical antioxidant activity of the $n$ hexane and methylene chloride extracts was evaluated using ABTS assay. The results in Table 3 showed that the antioxidant activity (\% inhibition) against ABTS radical was $36.5 \%$ and $86.3 \%$ respectively for the $n$-hexane and methylene chloride extracts, compared to ascorbic acid as standard with \% inhibition of $89.2 \%$.The results showed that methylene chloride extract had a potent antioxidant activity to scavenge ABTS radicals with nearly the same effect of ascorbic acid. There are limited previously published data about the ABTS radical scavenging activity of plant. For instance, Amutha et al (2014) studied the radical scavenging activity of ABTS of six solvent extracts of Cassia senna leaf growing in India. The inhibition percentages (\%) were $92 \%, 90.6 \%, 93 \%, 92 \%, 90.8 \%$, and $92 \%$ respectively for petroleum ether, benzene, chloroform, ethyl acetate, ethanol, and aqueous extracts (Amutha et al., 2014).Also, Jothi et al (2015) reported that the ABTS radical scavenging activity of different solvent extracts of the aerial part of Senna italica i.e., (methanol, ethanol, petroleum ether, benzene, and ethyl acetate), with inhibition percentages $49.84 \%, 43.18 \%, 36.84 \%, 29.92 \%$, and $40.18 \%$ at $100 \mu \mathrm{g} / \mathrm{ml}$ respectively for methanol, ethanol, petroleum ether, benzene, and ethyl acetate extracts(Jothi et al., 2015).

Table 3: Antioxidant activity of $n$-hexane and methylene chloride extracts of $S$. italica using ABTS assay.

\begin{tabular}{lcc}
\hline \multicolumn{1}{c}{ Sample } & Absorbance of samples & \% inhibition \\
\hline$n$-hexane & 0.324 & $36.5 \%$ \\
Methylene chloride & 0.070 & $86.3 \%$ \\
Ascorbic acid & 0.055 & $89.2 \%$ \\
Control of ABTS & 0.510 & $0 \%$ \\
\hline
\end{tabular}

\section{GC-MS investigations of n-hexane and methylene chloride extracts}

The chemical constituents were identified by comparing their mass spectra with those of their analogous reported by NIST, Wiley9, Mainlib, Replib libraries and/or authentic spectra
(Adams, 1995). The GC-MS analysis of the $n$-hexane extract of $S$. italica revealed the presence of forty-six compounds (Figure 2 and Table 4), representing $(93.69 \%)$ of the total composition. $n$ hexadecanoic acid (30\%), (Z,Z,Z)9,12,15-octadecadienoic acid (21\%), vitamin E (7.32\%), turmerone (7.28\%), phytol $(4.66 \%)$, curlone $(2.77 \%)$, squalene $(2.57 \%)$, and hexadecanoic acid, methyl ester $(1.94 \%)$ were identified as a major compounds in $n$-hexane extract. On the other hand, the GC-MS analysis of the methylene chloride extract revealed the presence of twenty-seven compounds (Figure 3 and Table 5), representing (95.44\%) of the total composition. 3-methyl-4-oxopentanoic acid(16.36\%), (E)-stilbene (11.86\%), 2,6-di-tert-butylphenol (10.70\%), 2-methoxy-4vinylphenol $(8.77 \%)$, N-ethylaniline $(6.06 \%)$, N,N-dimethyl-1phenylmethanamine(5.57\%), 3-(1-methylhept-1-enyl)-5-methyl2,5-dihydrofuran-2-one $(5.13 \%)$, trans-sinapyl alcohol(4.68\%), 1nonadecene $(4.18 \%)$, (E)5-eicosene $(4.04 \%)$, 3-buten-2-one, 4-(4hydroxy-2,2,6-trimethyl-7-oxabicyclo[4.1.0]hept-1-yl)- (2.66\%), and hexadecanoic acid methyl ester $(2.30 \%)$ were identified as a major compounds in methylene chloride extract. Moreover, the chemical structures of major compounds identified in the $n$-hexane extract and some selected fragmentation pattern are shown in (Figure 6), i.e., turmerone showed a base peak at $\mathrm{m} / \mathrm{z} 83.20$ $(100 \%)$ corresponding to the fragment with molecular formula $\left(\mathrm{C}_{5} \mathrm{H}_{7} \mathrm{O}\right)$, hexadecanoic acid, methyl ester showed a base peak at $\mathrm{m} / \mathrm{z} 74.20(100 \%)$ corresponding to the fragment (dimethyl ester) with molecular formula $\left(\mathrm{C}_{3} \mathrm{H}_{6} \mathrm{O}_{2}\right)$, and hexadecanoic acid showed a base peak at $\mathrm{m} / \mathrm{z} 73.20(100 \%)$ corresponding to the fragment (propionic acid) with molecular formula $\left(\mathrm{C}_{3} \mathrm{H}_{6} \mathrm{O}_{2}\right)$. On the other hand, the chemical structures of major compounds identified in the methylene chloride extract and some selected fragmentation pattern are shown in (Figure 7),i.e., N,N-dimethyl-1phenylmethanamine showed a base peak at $\mathrm{m} / \mathrm{z} 58.20(100 \%)$ corresponding to the fragment (tri-methylamine) with molecular formula $\left(\mathrm{C}_{3} \mathrm{H}_{8} \mathrm{~N}\right)$, 2-methoxy-4-vinylphenol showed a base peak (M.wt.) at $\mathrm{m} / \mathrm{z} 150.10$ (100\%), (E)-stilbene showed a base peak (M.wt.) at m/z 180.20 (100\%), and trans-sinapyl alcohol showed a base peak (M.wt.) at m/z 210.20 (100\%) (Adams, 1995). 


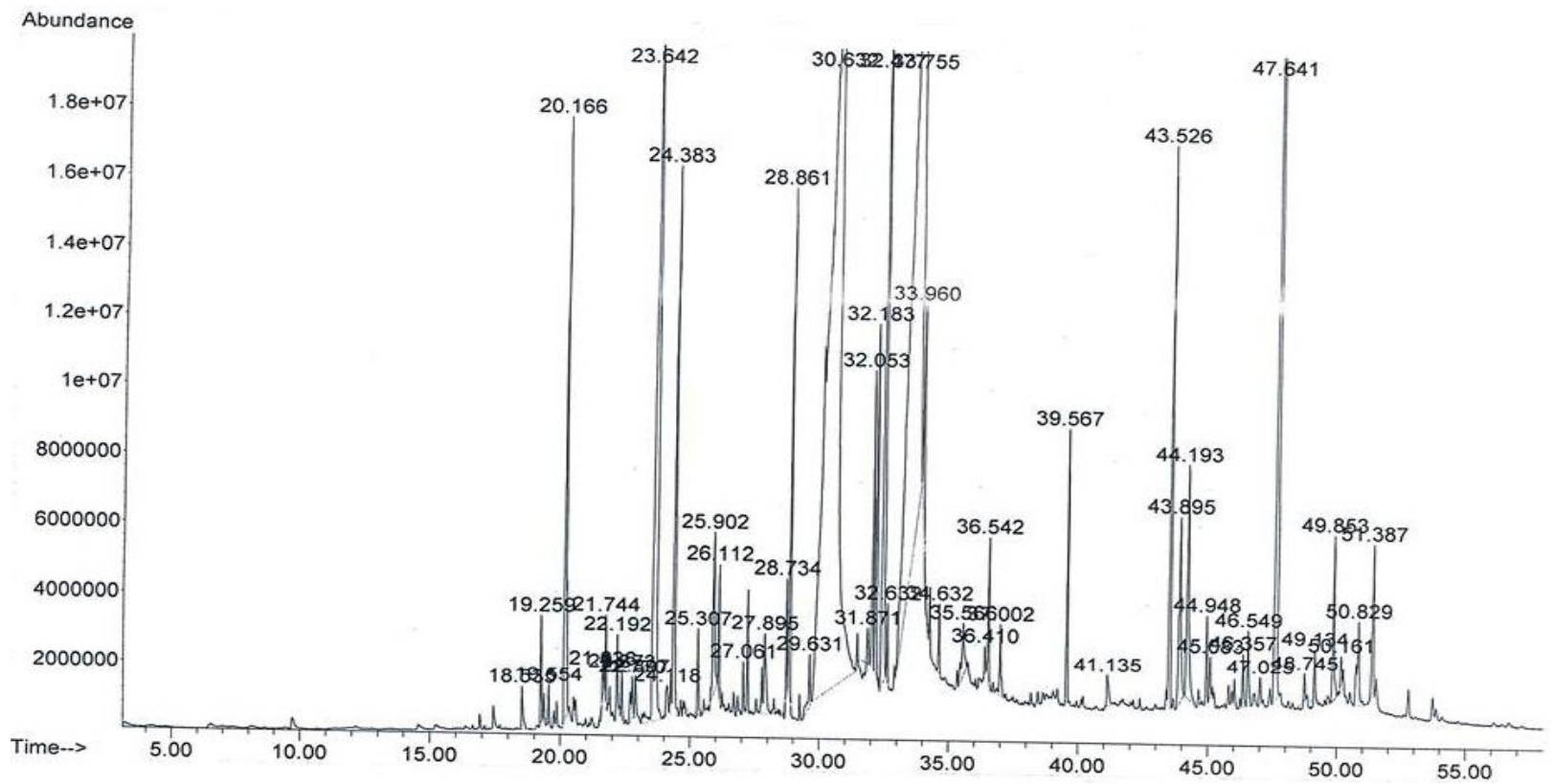

Fig. 2: Gas ion chromatogram of the of the $n$-hexane extract of $S$. italica aerial part.

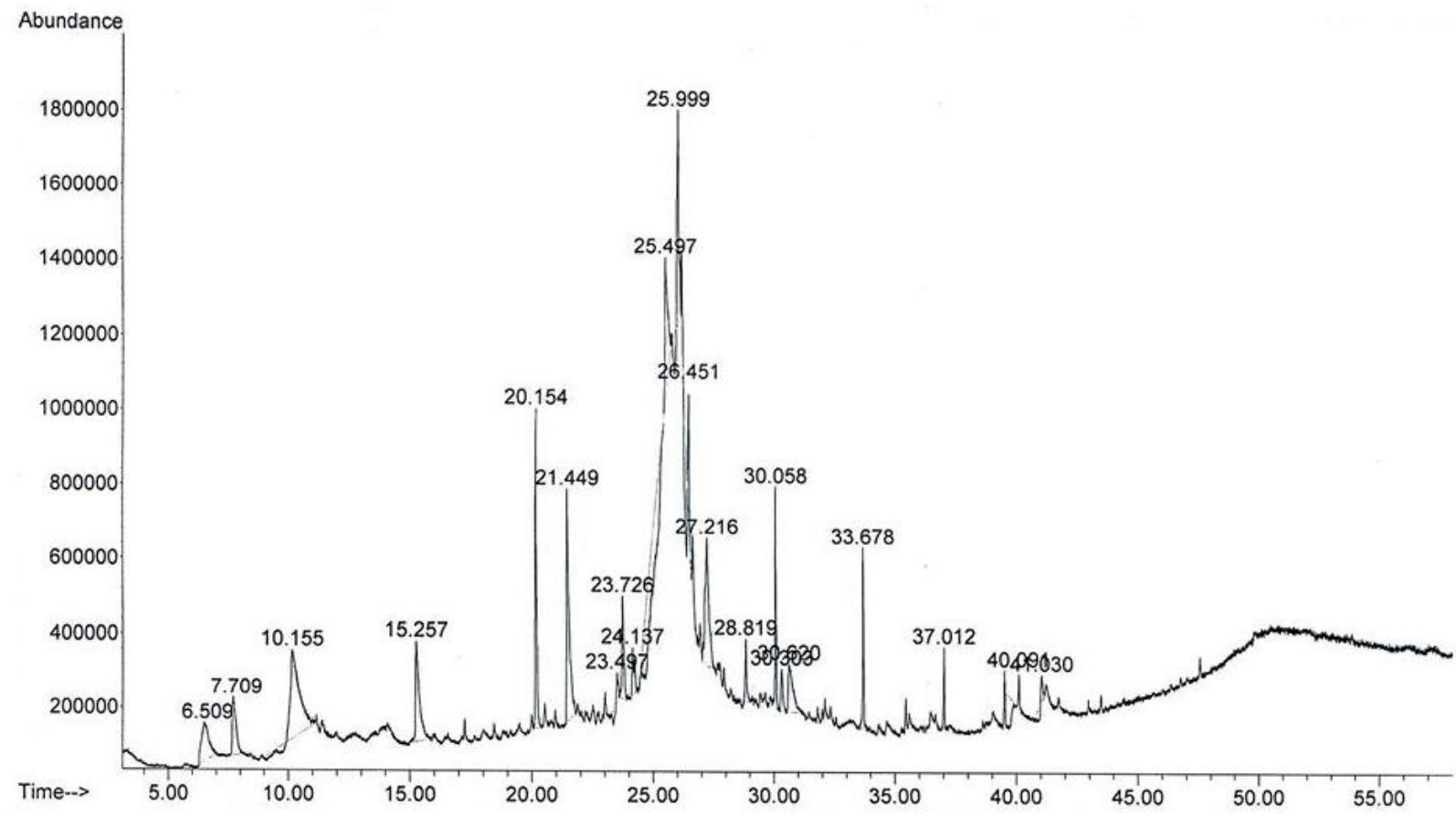

Fig. 3: Gas ion chromatogram of the methylene chloride extract of $S$. italica aerial part.

Reviewing the literature showed that, the GC-MS investigation of the $n$-hexane extract from Senna italica growing in Sudan led to identification of major components viz., 2,6,-disec-butylphenol (36.69\%), di- $n$-octylphthalate $(12.06 \%)$, eicosane $(5.46 \%)$, tetratriacontane $(4.87 \%)$, and 2,2'-methylenebis[6-(1,1dimethyl)-4-methylphenol (4.18\%)(Yagi et al., 2013). Also, the GC-MS analysis of the methanol extract of the Indian species revealed the presence of Seventeen components, and the major constituents were identified as; 3-O-methyl-D-glucose $(48.37 \%)$, 9,12,15-octadecatrienoic acid, (Z,Z,Z)- (16.30\%), $n$-hexadecanoic acid (11.70\%), 1-butanol, 3-methyl, formate (4.38\%), squalene (2.92\%), 3,7,11,15-tetramethyl-2-hexadecen-1ol (2.37\%), ricinoleic acid (2.26\%), phytol (1.64\%), 11dodecenoic acid, 10-hydroxy-, methyl ester (1.46\%), and 9,12octadecadienoic acid (Z,Z)- (1.47\%) (Sermakkani and Thangapandian, 2012). 
<smiles>CCCCC(C)C(C)CC(=O)C=C(C)C</smiles>

Library Search Report - ChemStation Integrator

Unknown Spectrum based on Apex

Abundance

Scan 3531 (23.640 min): 00401004.DDATA.MS

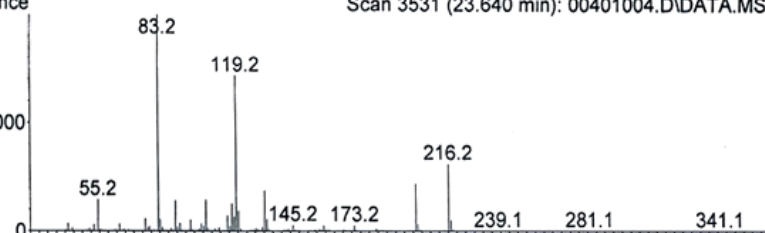

$\mathrm{m} / \mathrm{z} 83.20100 .00 \%$

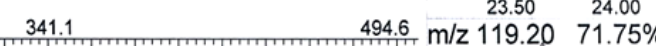

$\mathrm{m} / \mathrm{z}->$

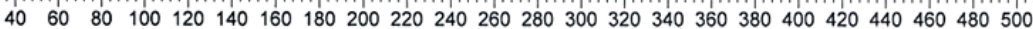




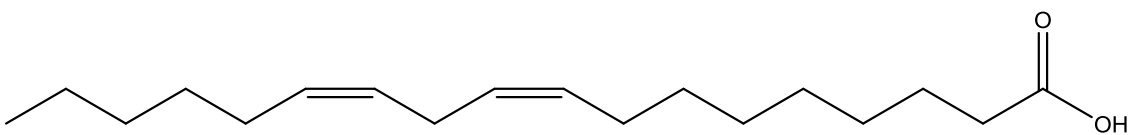

$(\mathrm{Z}, \mathrm{Z}) 9,12-$-Octadecadienoic acid

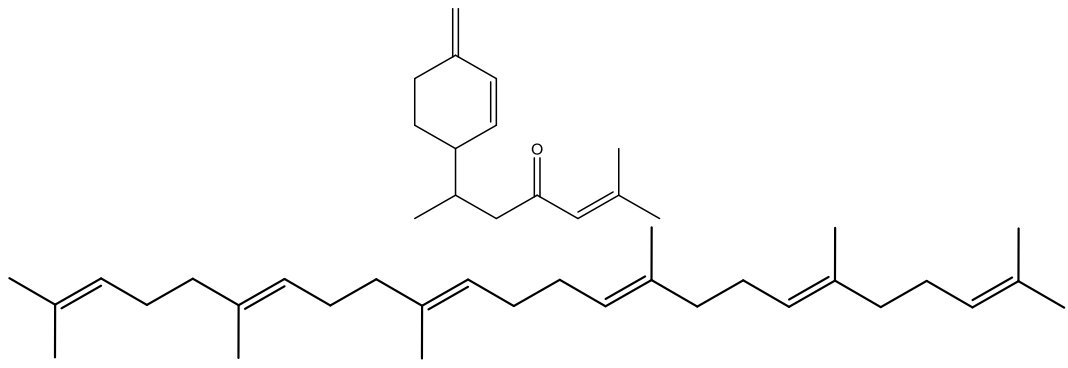

Squalene

Fig. 6: Major compounds identified in the $n$-hexane extract

Table 4: The compounds identified in the n-hexane extract of S. italica aerial part by GC/MS analyses.

\begin{tabular}{|c|c|c|c|c|c|}
\hline \multirow{2}{*}{ R.T } & \multicolumn{2}{|r|}{ No.Compound } & \multirow{2}{*}{ Area\% } & \multirow{2}{*}{ M.F. } & \multirow{2}{*}{$\mathbf{m} / \mathbf{z}$} \\
\hline & & Name & & & \\
\hline 18.534 & 1 & (E)-6,10-dimethylundeca-5,9-dien-2-one & 0.23 & $\mathrm{C}_{13} \mathrm{H}_{22} \mathrm{O}$ & 194 \\
\hline 19.261 & 2 & curcumene & 0.36 & $\mathrm{C}_{15} \mathrm{H}_{22}$ & 202 \\
\hline 19.552 & 3 & (-)-zingiberene & 0.09 & $\mathrm{C}_{15} \mathrm{H}_{24}$ & 204 \\
\hline 21.637 & 4 & 2,4-dimethylbenzyl 2,5-dimethylbenzoate & 0.05 & $\mathrm{C}_{18} \mathrm{H}_{20} \mathrm{O}_{2}$ & 268 \\
\hline 21.742 & 5 & cetene & 0.25 & $\mathrm{C}_{16} \mathrm{H}_{32}$ & 224 \\
\hline 22.190 & 6 & pyridine, 5-ethenyl-2-methyl & 0.37 & $\mathrm{C}_{8} \mathrm{H}_{9} \mathrm{~N}$ & 119 \\
\hline 22.370 & 7 & $\alpha$-cedrene & 0.17 & $\mathrm{C}_{15} \mathrm{H}_{24}$ & 204 \\
\hline 22.472 & 8 & $\beta$-cedrene & 0.19 & $\mathrm{C}_{15} \mathrm{H}_{24}$ & 204 \\
\hline 22.772 & 9 & zingiberenol & 0.29 & $\mathrm{C}_{15} \mathrm{H}_{26} \mathrm{O}$ & 222 \\
\hline 22.894 & 10 & $\mathrm{~N}, \mathrm{~N}$-dimethylaniline & 0.23 & $\mathrm{C}_{8} \mathrm{H}_{11} \mathrm{~N}$ & 121 \\
\hline 23.640 & 11 & turmerone & 7.28 & $\mathrm{C}_{15} \mathrm{H}_{20} \mathrm{O}$ & 216 \\
\hline 24.117 & 12 & 1,4-dimethyl-2-(3,7-dimethyloctyl)benzene & 0.22 & $\mathrm{C}_{18} \mathrm{H}_{30}$ & 246 \\
\hline 24.385 & 13 & curlone & 2.77 & $\mathrm{C}_{15} \mathrm{H}_{20} \mathrm{O}$ & 218 \\
\hline 25.305 & 14 & $(6 \mathrm{R}, 7 \mathrm{R})$-bisabolone & 0.25 & $\mathrm{C}_{15} \mathrm{H}_{24} \mathrm{O}$ & 220 \\
\hline 25.905 & 15 & verbenone & 0.97 & $\mathrm{C}_{10} \mathrm{H}_{14} \mathrm{O}$ & 150 \\
\hline 26.114 & 16 & 1-octadecene & 0.43 & $\mathrm{C}_{18} \mathrm{H}_{36}$ & 252 \\
\hline 27.063 & 17 & neophytadiene & 0.17 & $\mathrm{C}_{20} \mathrm{H}_{38}$ & 278 \\
\hline 27.896 & 18 & benzoic acid, 2-hydroxy-, phenylmethyl ester & 0.78 & $\mathrm{C}_{14} \mathrm{H}_{12} \mathrm{O}$ & 228 \\
\hline 28.734 & 19 & farnesyl acetone & 0.32 & $\mathrm{C}_{18} \mathrm{H}_{30} \mathrm{O}$ & 262 \\
\hline 28.862 & 20 & hexadecanoic acid, methyl ester & 1.94 & $\mathrm{C}_{17} \mathrm{H}_{34} \mathrm{O}_{2}$ & 270 \\
\hline 30.632 & 21 & $n$-hexadecanoic acid & 30.0 & $\mathrm{C}_{16} \mathrm{H}_{32} \mathrm{O}_{2}$ & 256 \\
\hline 31.872 & 22 & heptadecanoic acid & 0.12 & $\mathrm{C}_{17} \mathrm{H}_{34} \mathrm{O}_{2}$ & 270 \\
\hline 32.053 & 23 & $(\mathrm{Z}, \mathrm{Z}) 8,11$-octadecadienoic acid methyl ester & 1.20 & $\mathrm{C}_{19} \mathrm{H}_{34} \mathrm{O}_{2}$ & 294 \\
\hline 32.181 & 24 & $(\mathrm{Z}, \mathrm{Z}, \mathrm{Z}) 9,12,15$-Octadecatrienoic acid methyl ester & 1.66 & $\mathrm{C}_{19} \mathrm{H}_{34} \mathrm{O}_{2}$ & 294 \\
\hline 32.478 & 25 & phytol & 4.66 & $\mathrm{C}_{19} \mathrm{H}_{32} \mathrm{O}_{2}$ & 292 \\
\hline 32.629 & 26 & methyl stearate & 0.25 & $\mathrm{C}_{20} \mathrm{H}_{40} \mathrm{O}$ & 296 \\
\hline 33.753 & 27 & $(\mathrm{Z}, \mathrm{Z}) 9,12$-octadecadienoic acid & 21.00 & $\mathrm{C}_{18} \mathrm{H}_{32} \mathrm{O}_{2}$ & 280 \\
\hline 33.963 & 28 & octadecanoic acid & 0.77 & $\mathrm{C}_{18} \mathrm{H}_{36} \mathrm{O}_{2}$ & 284 \\
\hline 34.632 & 29 & methyl (2E,11E,13E)2,11,13-octadecatrienoate & 1.26 & $\mathrm{C}_{19} \mathrm{H}_{32} \mathrm{O}_{2}$ & 292 \\
\hline 35.564 & 30 & $(\mathrm{Z}, \mathrm{Z}, \mathrm{Z}) 9,12,15$-octadecatrienoic acid & 0.48 & $\mathrm{C}_{18} \mathrm{H}_{30} \mathrm{O}_{2}$ & 278 \\
\hline 36.408 & 31 & chrysophanic acid & 0.14 & $\mathrm{C}_{15} \mathrm{H}_{10} \mathrm{O}_{4}$ & 254 \\
\hline 36.452 & 32 & 4,8,12,16-tetramethylheptadecan-4-olide & 0.54 & $\mathrm{C}_{21} \mathrm{H}_{40} \mathrm{O}_{2}$ & 324 \\
\hline 37.002 & 33 & geranylgeraniol & 0.42 & $\mathrm{C}_{20} \mathrm{H}_{34} \mathrm{O}$ & 290 \\
\hline 41.136 & 34 & physcion & 0.21 & $\mathrm{C}_{16} \mathrm{H}_{12} \mathrm{O}_{5}$ & 284 \\
\hline 43.528 & 35 & squalene & 2.57 & $\mathrm{C}_{30} \mathrm{H}_{50}$ & 410 \\
\hline 44.949 & 36 & solanesol & 0.32 & $\mathrm{C}_{45} \mathrm{H}_{74} \mathrm{O}$ & 630 \\
\hline 46.358 & 37 & beta-Tocopherol & 0.28 & $\mathrm{C}_{28} \mathrm{H}_{48} \mathrm{O}_{2}$ & 416 \\
\hline 46.550 & 38 & gamma-Tocopherol & 0.37 & $\mathrm{C}_{28} \mathrm{H}_{48} \mathrm{O}_{2}$ & 416 \\
\hline 47.028 & 39 & fluorenone oxime & 0.14 & $\mathrm{C}_{13} \mathrm{H}_{9} \mathrm{~N}$ & 195 \\
\hline 47.639 & 40 & vitamin $\mathrm{E}$ & 7.32 & $\mathrm{C}_{29} \mathrm{H}_{50} \mathrm{O}_{2}$ & 430 \\
\hline 48.745 & 41 & campesterol & 0.04 & $\mathrm{C}_{28} \mathrm{H}_{48} \mathrm{O}$ & 400 \\
\hline 49.135 & 42 & stigmasterol & 0.18 & $\mathrm{C}_{29} \mathrm{H}_{48} \mathrm{O}$ & 412 \\
\hline 49.851 & 43 & beta-Sitosterol & 0.84 & $\mathrm{C}_{29} \mathrm{H}_{50} \mathrm{O}$ & 414 \\
\hline 50.160 & 44 & lupeol & 0.11 & $\mathrm{C}_{30} \mathrm{H}_{50} \mathrm{O}$ & 426 \\
\hline 50.830 & 45 & dammaradienol & 0.69 & $\mathrm{C}_{30} \mathrm{H}_{50} \mathrm{O}$ & 426 \\
\hline 51.388 & 46 & alpha-Tocopherol & 0.76 & $\mathrm{C}_{29} \mathrm{H}_{50} \mathrm{O}_{2}$ & 430 \\
\hline
\end{tabular}

R.T: Retention time. $\mathrm{m} / z$ [identity] (rel. abound. \%). M.F.: Molecular formula. 


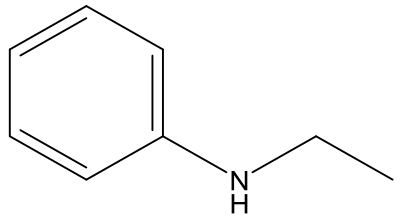

N-ethylaniline

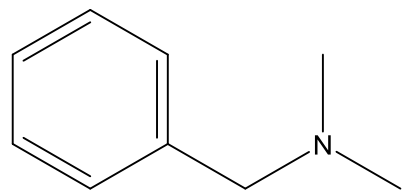

$\mathrm{N}, \mathrm{N}$-dimethyl-1-phenylmethanamine

Library Search Report - ChemStation Integrator

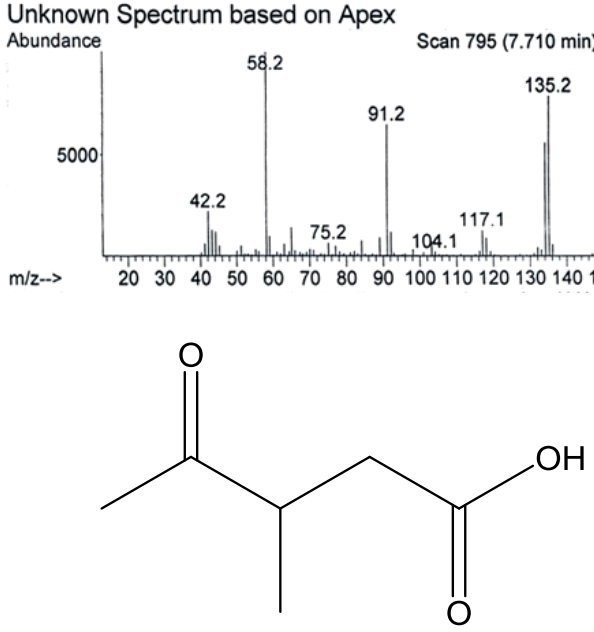

3-methyl-4-oxopentanoic acid $\mathrm{m} / \mathrm{z} 58.20100 .00 \%$

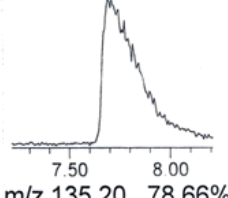

त

\section{Library Search Report - ChemStation Integrator}

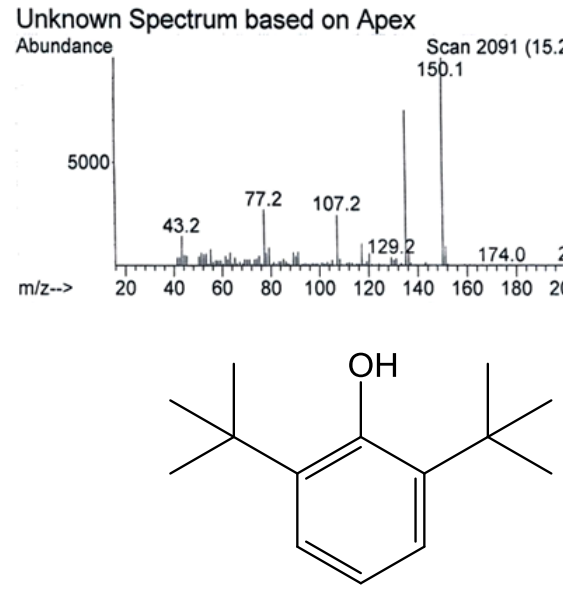

2,6-Di-tert-butylphenol

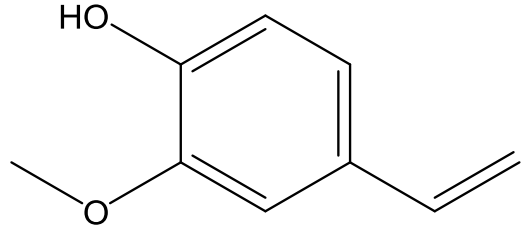

2-Methoxy-4-vinylphenol

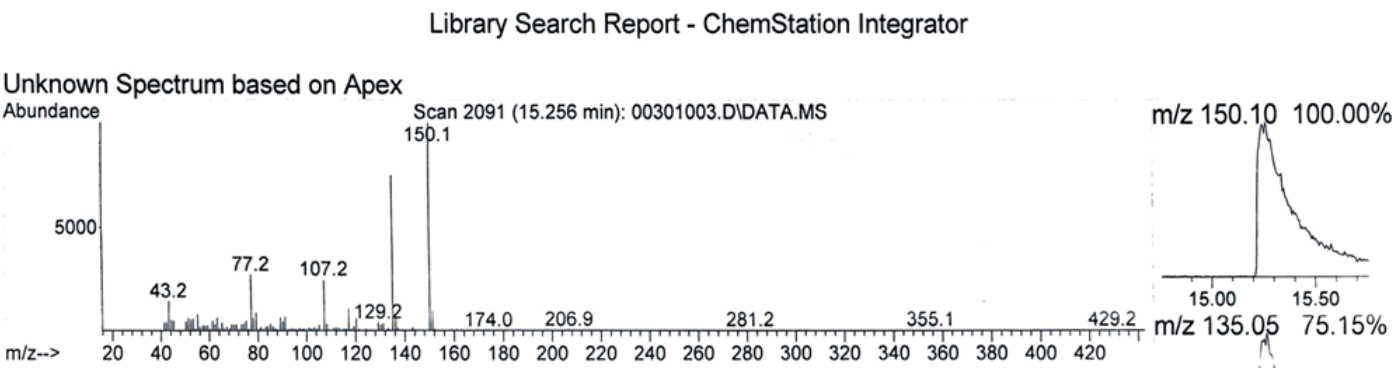

Library Search Report - ChemStation Integrator

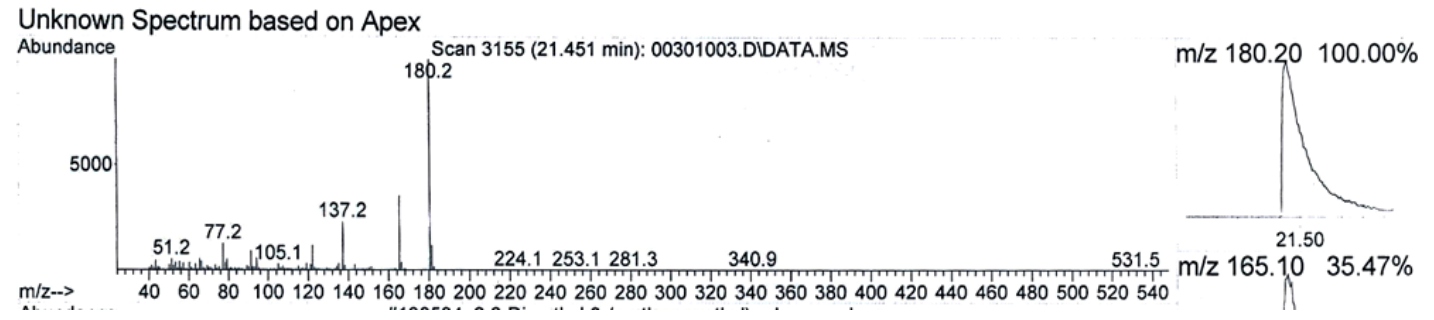




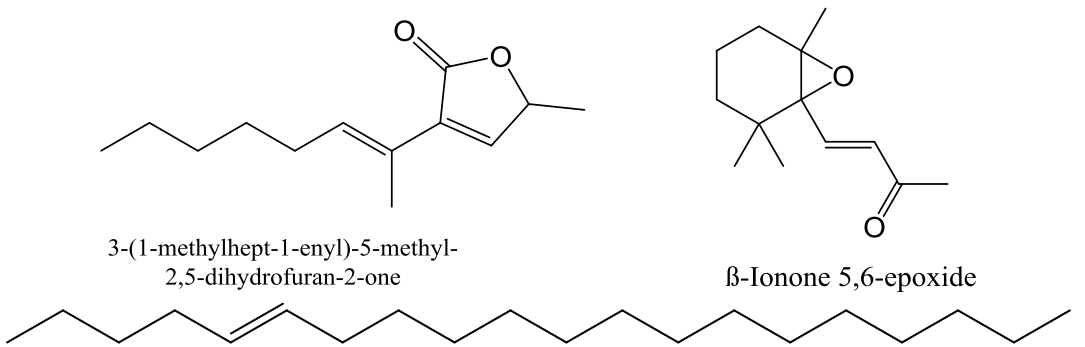

(E)5-Eicosene

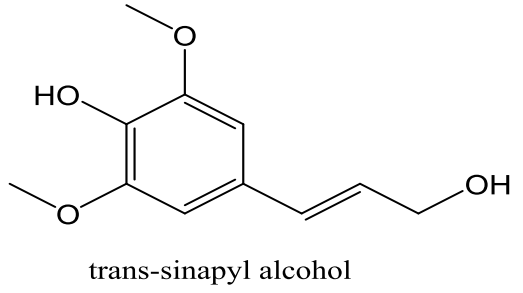

Library Search Report - ChemStation Integrator
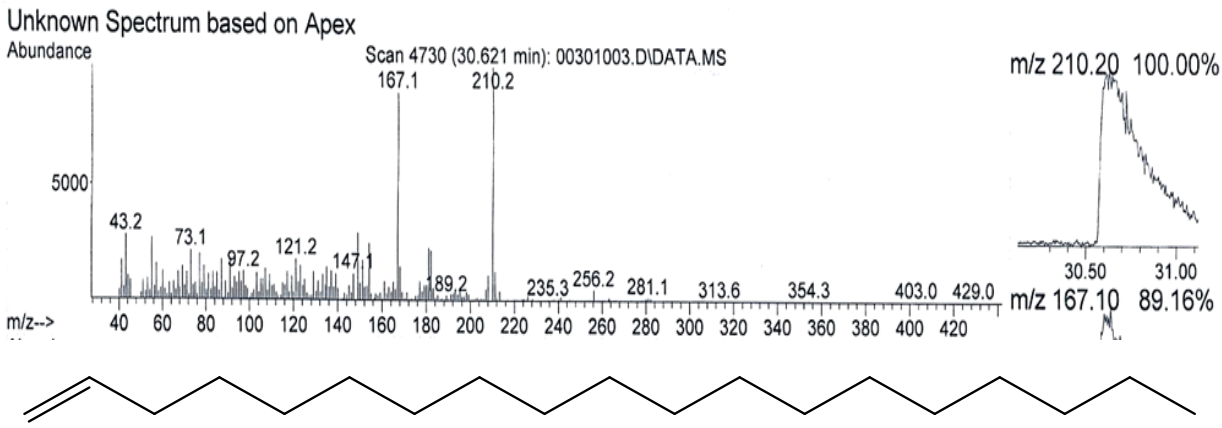

1-Nonadecene

Fig. 7: Major compounds identified in the methylene chloride extract.

Table 5: The compounds identified in the methylene chloride extract of $S$. italica aerial part by GC/MS analyses.

\begin{tabular}{|c|c|c|c|c|c|}
\hline \multirow[t]{2}{*}{ R.T } & \multicolumn{2}{|r|}{ Compound } & Area\% & \multirow[t]{2}{*}{ M.F. } & \multirow[t]{2}{*}{$\mathbf{m} / \mathbf{z}$} \\
\hline & No. & Name & & & \\
\hline 6.511 & 1 & N-ethylaniline & 6.06 & $\mathrm{C}_{8} \mathrm{H}_{11} \mathrm{~N}$ & 121 \\
\hline 7.710 & 2 & $\mathrm{~N}, \mathrm{~N}$-dimethyl-1-phenylmethanamine & 5.57 & $\mathrm{C}_{9} \mathrm{H}_{13} \mathrm{~N}$ & 135 \\
\hline 10.156 & 3 & 3-methyl-4-oxopentanoic acid & 16.36 & $\mathrm{C}_{6} \mathrm{H}_{10} \mathrm{O}_{3}$ & 130 \\
\hline 15.256 & 4 & 2-methoxy-4-vinylphenol & 8.77 & $\mathrm{C}_{9} \mathrm{H}_{10} \mathrm{O}$ & 150 \\
\hline 20.152 & 5 & 2,6-di-tert-butylphenol & 10.70 & $\mathrm{C}_{14} \mathrm{H}_{22} \mathrm{O}$ & 206 \\
\hline 21.451 & 6 & (E)-stilbene & 11.86 & $\mathrm{C}_{14} \mathrm{H}_{12}$ & 180 \\
\hline 23.500 & 7 & anisyl propionate & 0.32 & $\mathrm{C}_{11} \mathrm{H}_{14} \mathrm{O}_{3}$ & 194 \\
\hline 23.550 & 8 & 1,3-cyclohexadiene, 1-methyl-4-(1-methylethyl)- & 0.23 & $\mathrm{C}_{10} \mathrm{H}_{16}$ & 136 \\
\hline 23.727 & 9 & 3-(1-methylhept-1-enyl)-5-methyl-2,5-dihydrofuran-2-one & 5.13 & $\mathrm{C}_{13} \mathrm{H}_{20} \mathrm{O}_{2}$ & 208 \\
\hline 23.920 & 10 & B-Ionone 5,6-epoxide & 0.62 & $\mathrm{C}_{13} \mathrm{H}_{20} \mathrm{O}_{2}$ & 208 \\
\hline 24.135 & 11 & 3-buten-2-one, 4-(4-hydroxy-2,2,6-trimethyl-7-oxabicyclo[4.1.0]hept-1-yl)- & 2.66 & $\mathrm{C}_{13} \mathrm{H}_{20} \mathrm{O}_{3}$ & 224 \\
\hline 25.497 & 12 & (E)-4-(3-Hydroxyprop-1-en-1-yl)-2-methoxyphenol & 1.36 & $\mathrm{C}_{10} \mathrm{H}_{12} \mathrm{O}_{3}$ & 180 \\
\hline 26.452 & 13 & orcinol & 0.22 & $\mathrm{C}_{7} \mathrm{H}_{8} \mathrm{O}_{2}$ & 124 \\
\hline 28.816 & 14 & hexadecanoic acid methyl ester & 2.30 & $\mathrm{C}_{17} \mathrm{H}_{34} \mathrm{O}_{2}$ & 270 \\
\hline 29.916 & 15 & pentadecanoic acid 14-methyl-methyl ester & 1.35 & $\mathrm{C}_{17} \mathrm{H}_{34} \mathrm{O}_{2}$ & 270 \\
\hline 30.056 & 16 & (E)5-eicosene & 4.04 & $\mathrm{C}_{20} \mathrm{H}_{40}$ & 280 \\
\hline 30.106 & 17 & 1-octadecene & 0.65 & $\mathrm{C}_{18} \mathrm{H}_{36}$ & 252 \\
\hline 30.621 & 18 & trans-sinapyl alcohol & 4.68 & $\mathrm{C}_{11} \mathrm{H}_{14} \mathrm{O}_{4}$ & 210 \\
\hline 31.633 & 19 & desaspidinol & 1.38 & $\mathrm{C}_{11} \mathrm{H}_{14} \mathrm{O}_{4}$ & 210 \\
\hline 33.677 & 20 & 1-nonadecene & 4.18 & $\mathrm{C}_{19} \mathrm{H}_{38}$ & 266 \\
\hline 34.674 & 21 & 1-docosanol & 1.34 & $\mathrm{C}_{22} \mathrm{H}_{46} \mathrm{O}$ & 326 \\
\hline 36.670 & 22 & 1-tetracosanol & 0.94 & $\mathrm{C}_{24} \mathrm{H}_{50} \mathrm{O}$ & 354 \\
\hline 37.014 & 23 & 1-docosene & 1.86 & $\mathrm{C}_{22} \mathrm{H}_{44}$ & 308 \\
\hline 40.093 & 24 & 9-nonadecene & 0.23 & $\mathrm{C}_{19} \mathrm{H}_{38}$ & 266 \\
\hline 40.396 & 25 & 13-tetradecen-1-ol acetate & 1.90 & $\mathrm{C}_{16} \mathrm{H}_{30} \mathrm{O}_{2}$ & 254 \\
\hline 41.363 & 26 & cycloeicosane & 0.49 & $\mathrm{C}_{20} \mathrm{H}_{40}$ & 280 \\
\hline 42.031 & 27 & 8-methoxy-7-methyldibenzo[b,f]oxepine-1,6-diol & 0.24 & $\mathrm{C}_{16} \mathrm{H}_{14} \mathrm{O}_{4}$ & 270 \\
\hline
\end{tabular}




\section{CONCLUSION}

In the current study, the $n$-hexane and methylene chloride extracts of Senna italic aerial parts growing in Egypt were investigated for their antimicrobial, ABTS antioxidant and anticancer activities. The methylene chloride extract showed a noticeable activity than the $n$-hexane in the above mentioned assays. Furthermore, the two extracts were subjected to GC-MS analyses. $n$-hexadecanoic acid (30\%), (Z,Z,Z)9,12,15octadecadienoic acid (21\%), vitamin E (7.32\%), turmerone (7.28\%), phytol $(4.66 \%)$, curlone $(2.77 \%)$ were recorded as a major compounds in $n$-hexane.Also,3-methyl-4-oxopentanoic acid $(16.36 \%), \quad($ E)-stilbene $\quad(11.86 \%), \quad 2,6$-di-tert-butylphenol (10.70\%), 2-methoxy-4-vinylphenol (8.77\%), N-ethylaniline (6.06\%), N,N-dimethyl-1-phenylmethanamine (5.57\%), 3-(1methylhept-1-enyl)-5-methyl-2,5-dihydrofuran-2-one $\quad(5.13 \%)$, trans-sinapyl alcohol(4.68\%), 1-nonadecene (4.18\%)were recognized as major compounds in methylene chloride extract. The identified compounds may be responsible for the antimicrobial, antioxidant and anticancer activities.

\section{Financial support and sponsorship: Nil.}

Conflict of Interests: There are no conflicts of interest.

\section{REFERENCES}

Adams RP. Identification of essential oil components by gas chromatography-mass spectrometry. Allured Publishing Corporation, Carol Stream, Illinois, USA: 1995.

Al-Naimy EH, Al-Amery MM, Al-Azy RM. Antibacterial and cytogenetic effect of Cassia italica leaf extract on albino male mice. J AlNahrain Univ, 2010;13:132-139.

Al-Said MS. Traditional medicinal plants of Saudi Arabia.Am J Chin Med, 1993;21:291-298.

Amutha PR, Suganya V, Suganthi B, Aishwarya K. Evaluation of free radical scavenging activity of selected parts of Cassia senna.Int $\mathrm{J}$ Pharm Sci Rev Res, 2014;27:74-78.

Asfour HZ, Ibrahim SRM, Mohamed GA.Antimicrobial activity of extracts and compounds isolated from Cassia italica aerial parts.Int $\mathrm{J}$ Phytopharm Res, 2015;6:95-100.

Boik J. Natural compounds in cancer therapy. Minnesota, USA: Oregon Medical Press, 2001.

Cowan MM. Plant products as antimicrobial agents. Clin Microbiol Rev, 1999;12:564-582.

Dabai YU, Kawo AH, Aliyu RM. Phytochemical screening and antibacterial activity of the leaf and root extracts of Senna italica. Afr J Pharm Pharmacol, 2012;6:914-918.

El-Gazzar ABA, Youssef MM, Youssef AMS, Abu-Hashem AA, Badria FA.Design and synthesis of azolopyrimidoquinolines, pyrimidoquinazolinesas anti-oxidant, anti-inflammatory and analgesic activities. Eur J Med Chem, 2009;44:609-624.

Ghareeb MA, Refahy LA, Saad AM, Osman NS, Abdel-Aziz MS, El-Shazly MA, et al.In vitro antimicrobial activity of five Egyptian plant species. J Appl Pharm Sci, 2015;5: 045-049.

Ghareeb MA, Shoeb HA, Madkour HMF, Refaey LA, Mohamed MA, Saad AM.Antioxidant and cytotoxic activities of Tectona grandis Linn leaves. Int J Phytopharmacol, 2014;5:143-157.

Ghareeb MA, Shoeb HA, Madkour HMF, Refahy LA, Mohamed MA, Saad AM.Radical scavenging potential and cytotoxic activity of phenolic compounds from Tectona grandis (Linn.).Global J Pharmacol, 2013;7:486-497.
Hennebelle T, Weniger B, Joseph H, Sahpaz S, Bailleul F, Senna alata. Fitoterapia, 2009;80:385-393.

Jothi RS, Bharathy V, Thayakumari FU.Antioxidant potential of aerial part of Senna italica sub species micrantha Mill. J Pharm Sci Res, 2015;7:621-625.

Kuete V,Wiench B, Alsaid MS, Alyahya MA, Fankam AG, Shahat AA, et al. Cytotoxicity, mode of action and antibacterial activities of selected Saudi Arabian medicinal plants. BMC Complementary Altern Med, 2013;13: 1-11.

Magano SR, Thembo KM, Ndlovu SM, Makhubela NFH. The anti-tick properties of the root extracts of Senna italica subsp. arachoides. Afr J Biotechnol, 2008;7:476-481.

Maleho AL. Isolation and characterization of antibacterial compounds from five selected plants used against bacteria which infects wounds.M.Sc. Thesis, Faculty of Science and Agriculture, School of Molecular and Life Sciences, University of Limpopo, 2015.

Masoko P, Gololo SS, Mokgotho MP, Eloff JN, Howard RI, Mampuru LJ. Evaluation of the antioxidant, antibacterial, and antiproliferative activities of the acetone extract of the roots of Senna italica (Fabaceae).Afr J Tradit Complement, Altern Med, 2010; 7:138148.

Mauceri HJ, Hanna NN, Beckett MA, Gorski DH, Staba MJ, Stellato KA, et al. Combined effects of agiostatin and ionizing radiation in antitumour therapy. Nature, 1998;394:287-291.

Mokgotho MP, Gololo SS, Masoko P, Mdee LK, Mbazima V, Shai LJ, et al. Isolation and chemical structural characterisation of a compound with antioxidant activity from the roots of Senna italica. EvidBased Compl Alt Med, 2013;1-6.

Murray R, Rosenthal S, Kobayashi S, Pfaller A. Medical Microbiology. $3^{\text {rd }}$ ed. St. Louis: Mosby, 1998:16.

Randell BR, Barlow BA. Senna. In: George AS (executive editor). Flora of Australia. Australian Government Publishing Service: Canberra, Australia, Vol. 12, 1998; 89-138.

Sardari A, Gholamreza M, Daneshtalab M. Phytopharmaceuticals. Part 1: Antifungal activity of selected Iranian and Canadian plants. Pharm Biol, 1998;36:180-188.

Schwartsmann G, Ratain MJ, Cragg GM, Wong JE, Saijo N, Parkinson DR, et al. Anticancer drug discovery and development throughout the world. J Clin Oncol, 2002;20:47S-59S.

Sermakkani M, Thangapandian V. GC-MS analysis of Cassia italica leaf methanol extract. Asian J Pharm ClinRes, 2012;5: 90-94.

Shoeb HA, Madkour HMF, Refahy LA, Mohamed MA, Saad AM, Ghareeb MA.Antioxidant and cytotoxic activities of Gmelina arborea (ROXB.) leaves.Br J Pharm Res, 2014;4:125-144.

Suffness M, Pezzuto JM: Assays related to cancer drug discovery. In Methods in Plant Biochemistry: Assays for Bioactivity. Edited by Hostettmann K. London: 6. Academic Press; 1990:71-133.

Tshikalange TE, Meyer JJM, Hussein AA. Antimicrobial activity, toxicity and the isolation of a bioactive compound from plants used to treat sexually transmitted diseases. J Ethnopharmacol, 2005;96: 515-519.

Yagi S, El Tigani S, Ali M, Elkhidir I, Mohammed AMA.Chemical constituents and insecticidal activity of Senna italica Mill.from the Sudan. Int Lett Chem Phys Astron, 2013;9:146-151.

\section{How to cite this article:}

Madkour HMF, Ghareeb MA, Abdel-Aziz MS, Khalaf OM, Saad AM, El-Ziaty AK, Abdel-Mogib M. Gas chromatography-mass spectrometry analysis, antimicrobial, anticancer and antioxidant activities of $n$-hexane and methylene chloride extracts of Senna italica. J App Pharm Sci, 2017; 7 (06): 023-032. 